\title{
Pengaruh Promosi Kesehatan Metode Ceramah Dan Leaflet Terhadap Peningkatan Pengetahuan Masyarakat Tentang Demam Berdarah Dengue Di Kecamatan Karangbinangun Kabupaten Lamongan
}

\author{
Anggreani Ayu Saraswati ${ }^{1}$, Mimatun Nasihah ${ }^{2}$, Marsha Savira Agatha Putri ${ }^{2^{*}}$ \\ ${ }^{1}$ Mahasiswa Program Studi Kesehatan Lingkungan, Universitas Islam Lamongan \\ ${ }^{2}$ Dosen Program Studi Kesehatan Lingkungan Universitas Islam Lamongan
}

*Corespondence author: marshasavira@unisla.ac.id, Telp: 085748804233

Received: 30 Juni 2020; Accepted: 29 September 2020; Published: 29 September 2020

\begin{abstract}
Abstrak
Sanitasi lingkungan yang buruk dapat meningkatkan kasus penyakit DBD. Penyakit DBD merupakan penyakit mematikan. Jumlah kasus di Indonesia tercatat tahun 2017 sebanyak 68.407 orang. Lamongan merupakan salah satu wilayah KLB di Jawa Timur, terjadi peningkatan kasus 2 kali lipat pada periode yang sama yakni dari 23 kasus bulan Januari 2014 meningkat 49 kasus pada bulan Januari 2015, jumlah kasus terus meningkat dan sampai hari sabtu tanggal 31 Januari 2015 laporan ditutup dengan jumlah kasus 86 penderita yang tersebar 19 Kecamatan. Salah satu Kecamatan di Kabupaten Lamongan adalah Karangbinangun, tindakan pencegahan penyakit DBD antara lain dengan cara kegiatan promosi kesehatan guna meningkatkan pengetahuan, sikap dan kebiasaan keluarga. Penelitian ini untuk mengetahui pengaruh metode ceramah dan metode leaflet terhadap peningkatan pengetahuan masyarakat tentang demam berdarah dengue. penelitian ini menggunakan quasy experiment dengan pre-test dan post-test two group design lalu uji analisis menggunakan $T$ paired dan man whitney. Kesimpulan hasil penelitian ini dalah Pemberian promosi kesehatan dengan menggunakan metode ceramah lebih efektif dibandingkan dengam metode leaflet untuk mempengaruhi perubahan pengetahuan responden dengan nilai $p=0.000$. Saran untuk penelitian selanjutnya Pada peneliti selanjutnya diharapkan untuk memperhatikan faktor-faktor yang dapat mengurangi keefektifan pemberian promosi kesehatan seperti kebisingan, letak ruang dan lain-lain.
\end{abstract}

Kata kunci: promosi kesehatan, metode ceramah, metode leaflet, demam berdarah dengue 


\section{Pendahuluan}

Seperti kita ketahui salah satu upaya mewujudkan tujuan Pembangunan Kesehatan Indonesia Sehat yaitu melalui sanitasi lingkungan yang baik. Sanitasi lingkungan adalah status kesehatan suatu lingkungan yang mencakup perumahan, pembuangan kotoran, penyediaan air bersih dan sebagainya. Sanitasi lingkungan ditujukan untuk memenuhi persyaratan lingkungan yang sehat dan nyaman (Notoadmojo, 2003). Sanitasi lingkungan merupakan faktor penting yang harus diperhatikan, terutama sarana air bersih, ketersediaan jamban, pengolahan air limbah, pembuangan sampah, dan pencemaran tanah. Dampak dari sanitasi lingkungan yang tidak terjaga kebersihannya salah satunya adalah penyakit DBD.

Demam Berdarah Dengue (DBD) atau Dengue Hemorrhagic Fever (DHF) adalah penyakit yang berhubungan dengan sanitasi lingkungan yang buruk disebabkan oleh virus dengue yang ditularkan oleh nyamuk Aedes aegypti. Pertama kali diketahui tahun 1779 di Mesir tepatnya Kairo dan pada tahun yang sama ada kejadian di Asia yaitu di Batavia yang sekarang sudah bernama Jakarta (Kurniawan, 2016). Namun sebenarnya demam berdarah di Indonesia pertama kali ditemukan di kota Surabaya pada tahun 1968, dimana sebanyak 58 orang diantaranya meninggal dunia dengan (angka kematian (AK): 41,3\%). Sejak saat itu, penyakit ini menyebar luas ke seluruh Indonesia (Achmadi, 2010).

Jawa Timur merupakan salah satu daerah endemik DBD. Berdasarkan data insiden DBD Provinsi Tahun 2017, Jawa Timur termasuk ke dalam Provinsi berwarna merah yang berarti Provinsi dengan insiden Kejadian Luar Biasa (KLB) (Anonim, 2018). Menurut Dinas Komunikasi dan Informatika Jawa Timur pada tahun 2018, terdapat 7 kota di Jawa Timur yang termasuk dalam kota KLB DBD. Daerah itu antara lain Kab. Kediri, Kab. Sumenep, Kab. Jember, Kab. Lamongan, Kab. Mojokerto, Kota Madiun, dan Kab. Pamekasan. Kondisi ini semakin memperparah reputasi Jawa Timur di bidang kesehatan.

Lamongan merupakan salah satu wilayah KLB di Jawa Timur, KLB ditetapkan hari senin tanggal 26 Januari 2015 setelah terjadi peningkatan kasus 2 kali lipat pada periode yang sama yakni dari 23 kasus bulan Januari 2014 meningkat 49 kasus pada bulan Januari 2015, jumlah kasus terus meningkat dan sampai hari sabtu tanggal 31 Januari 2015 laporan ditutup dengan jumlah kasus 86 penderita yang tersebar 19 Kecamatan atau 19 Puskesmas (Anonim, 2019). 
Salah satu faktor penting yang menyebabkan tingginya angka masyarakat yag terjangkit DBD adalah perilaku masyarakat dalam menjaga kebersihan lingkungan yang kurang . Peran aktif dari masyarakat diperlukan untuk mencegah penularan penyakit DBD seperti kegiatan masyarakat gotong royong dalam membersihkan lingkungan atau 3M Plus (menutup, menguras, mengubur, pegunaan lotion dan obat anti nyamuk, kelambu, pemasangan kasa pada ventilasi maupun fogging (Pantouw, 2017).

Pengetahuan masyarakat tentang DBD sangat penting dalam rangka membentuk sikap dan praktik dalam pencegahan DBD. Penerimaan praktik baru didasari oleh pengetahuan, kesadaran dan sikap yang positif akan bersifat langgeng. Sedangkan sikap merupakan respon yang masih tertutup dan belum otomatis terwujud sehingga diperlukan adanya intervensi yang dapat menghasilkan suatu tindakan (Achmadi, 2012). Tindakan pencegahan penyakit DBD antara lain dengan cara kegiatan promosi kesehatan memberikan wawasan dan pendidikan yang tepat mengenai kualitas dan sanitasi yang layak untuk penekanan jumlah penyakit DBD. Berdasarkan penelitian Effendi (2018), upaya penanggulangan DBD tidak hanya pada aspek kuratif dan rehabilitatif saja, melainkan dari aspek promotif dan preventif juga menjadi penting. Programprogram kesehatan perlu selalu disosialisasikan secara terus-menerus. Berkenaan dengan hal ini, maka diperlukan media promosi kesehatan yang efektif sesuai kebutuhan masyarakat. Kegiatan promosi kesehatan bisa dilakukan melalui beberapa media seperti media cetak, media elektronik, media luar ruang dan media lain.

Menurut penelitian Alfianur (2017) menyebutkan usaha meningkatkan pengetahuan masyarakat tentang pencegahan penyakit DBD melalui pendidikan kesehatan, media pendidikan kesehatan sangat berperan penting karena media tersebut akan mempermudah penerimaan pesan kesehatan bagi masyarakat. Berbagai media atau alat bantu pendidikan, media leaflet adalah media yang umum dan sering digunakan oleh petugas kesehatan saat melakukan pendidikan kesehatan karena selain bentuknya lembaran yang dilipat dan mudah dibawa tapi juga memuat banyak informasi berupa kalimat maupun gambar. Dalam hal ini dimungkinkan media leaflet akan efektif dalam meningkatkan pengetahuan masyarakat. Sedangkan metode yang paling umum digunakan dalam masyarakat adalah metode ceramah. Oleh sebab itu dalam penelitian ini peneliti menggunakan metode ceramah dan leaflet Penelitian ini bertujuan untuk mengetahui efektivitas media promosi kesehatan terhadap peningkatan pengetahuan masyarakat tentang penyakit DBD. 


\section{Metode Penelitian}

Penelitian ini dilakukan di Kecamatan Karangbingun. Rancangan penelitian yang akan dilaksanakan menggunakan quasy experiment dengan pre-test dan post-test two group design. Penelitian ini bertujuan untuk mengetahui Sampel didapat dengan simple random sampling perbedaan pengaruh pada kedua kelompok yaitu kelompok ceramah dan kelompok leaflet. Sampel dari penelitian ini adalah penelitian dilakukan di empat desa yang mempunyai kasus DBD tertinggi, sedang dan rendah yaitu Desa A, Desa B, Desa C dan Desa D. Responden dipilih ibuibu PKK dan Posyandu dari masing-masing desa. Instrumen dalam penelitian ini menggnakan kuesioner dan lembar observasi.

Analisa data menggunakan uji normalitis data menggunakan uji Kolmogorov Smirnov untuk mengetahui data itu berdistribusi normal atau tidak secara statistik. Analisis data hasil pretest dan post-test menggunakan uji berpasangan (paired t-test), untuk mengetahui perbedaan ratarata antara pengetahuan, sikap dan kebiasaan sebelum dan sesudah diberi perlakuan. Dasar pengambilan keputusan uji berpasangan yaitu, jika nilai Sig.(2-tailed) $<0.05$, maka terdapat perbedaan yang signifikan. Setelah di temukan hasil dari uji tersebut lalu ditentukan keefektifan dengan menggunakan uji Mann whitney untuk menentukan perlakuan yang paling efektif antara metode ceramah dengan metode leaflet.

\section{Hasil dan Pembahasan}

Hasil penelitian di Kecamatan Karangbinangun didapatkan hasil tentang pengetahuan DBD sebagai berikut:

\subsection{Karakteristik Responden}

Tabel 1. Distribusi karakteristik responden berdasarkan umur, pekerjaan dan pendidikan

\begin{tabular}{l|c|c|c|c}
\hline Karakteristik & \multicolumn{2}{|c|}{$\begin{array}{c}\text { Kelompok ceramah } \\
\text { (Desa A dan Desa B) }\end{array}$} & \multicolumn{2}{c}{$\begin{array}{c}\text { Kelompok leaflet } \\
\text { (Desa C dan Desa D) }\end{array}$} \\
\cline { 2 - 5 } & $\begin{array}{l}\text { Jumlah } \\
\text { (orang) }\end{array}$ & Persentase (\%) & $\begin{array}{c}\text { Jumlah } \\
\text { (orang) }\end{array}$ & Persentase (\%) \\
\hline Umur & & & & \\
\hline $20-35$ & 8 & 13 & 21 & 35 \\
$36-45$ & 24 & 40 & 18 & 30 \\
$46-55$ & 22 & 37 & 17 & 28 \\
$56-65$ & 6 & 10 & 4 & 7 \\
Jumlah & $\mathbf{6 0}$ & $\mathbf{1 0 0}$ & $\mathbf{6 0}$ & $\mathbf{1 0 0}$ \\
\hline Pekerjaan & & & & \\
\hline
\end{tabular}




\begin{tabular}{l|c|c|c|c}
\hline Ibu Rumah Tangga & 40 & 66,6 & 46 & 77 \\
PNS & 1 & 1,6 & 2 & 3 \\
Swasta & 2 & 3,3 & 4 & 7 \\
Wiraswasta & 5 & 8,3 & 3 & 5 \\
Buruh & 12 & 20 & 5 & 8 \\
Jumlah & $\mathbf{6 0}$ & $\mathbf{1 0 0}$ & $\mathbf{6 0}$ & $\mathbf{1 0 0}$ \\
\hline Pendidikan & & & & \\
\hline Tidak Sekolah & 2 & 3,3 & 0 & 0 \\
SD & 11 & 18,3 & 15 & 25 \\
SLTP & 17 & 28,3 & 14 & 23 \\
SMA & 27 & 45 & 29 & 48 \\
Akademi & 0 & 0 & 0 & 0 \\
Sarjana (S1) & 3 & 5 & 2 & 3 \\
Jumlah & $\mathbf{6 0}$ & $\mathbf{1 0 0}$ & $\mathbf{6 0}$ & $\mathbf{1 0 0}$ \\
\hline
\end{tabular}

Berdasarkan Tabel 1. menunjukkan banyaknya pekerjaan responden pada kelompok ceramah dan leaflet dalam penelitian ini adalah ibu rumah tangga sebanyak 40 orang $(66,6 \%)$ pada kelompok ceramah dan pada kelompok leaflet sebanyak 46 orang (77\%) dengan umur mulai 20 hingga 65 tahun. Kelompok ceramah sebanyak 24 orang (40\%) dan pada kelompok leaflet sebanyak 21 orang (35\%). Mayoritas pendidikan terakhir responden pada kedua kelompok yaitu SMA, pada kelompok ceramah sebanyak 27 orang (45\%) sedangkan pada kelompok leaflet sebanyak 29 orang (48\%) dan yang paling sedikit tidak sekolah pada kelompok ceramah sebanyak 2 orang $(3,3 \%)$.

Perlu ditekankan bahwa seseorang yang berpendidikan rendah tidak berarti mutlak berpengalaman rendah pula. Peningkatan pengetahuan tidak mutlak diperoleh pada di pendidikan formal, akan tetapi juga dapat diperoleh pada pendidikan non formal (Erfandi, 2009). Umur responden terbanyak kelompok ceramah 24 orang (40\%) berusia 36-45 tahun. Kelompok leaflet sebanyak 21 orang (35\%) berusia 20-35 tahun. Diasumsikan bahwa perbedaan umur responden pada kelompok ceramah dan kelompok leaflet memiliki pemahaman yang sama karena responden berpendidikan SMA.

Karakteristik pekerjaan pada penelitian ini terbanyak untuk kelompok ceramah 40 orang $(66,6 \%)$ dan kelompok leaflet 21 orang (35\%) sebagai ibu rumah tangga. Ibu rumah tangga dianggap sebagai orang yang paling memperhatikan anggota keluarga dan kebersihan lingkungan rumah. Menurut Thomas yang dikutip oleh Nursalam (2003) pekerjaan adalah kebutuhan yang harus dilakukan terutama untuk menunjang kehidupannya dan kehidupan keluarganya, tapi 
menurut penelitian Kusumawati (2014), tidak ada hubungan antara pekerjaan dan tingkat pengetahuan.

\subsection{Evaluasi tingkat Pengetahuan responden tentang DBD}

Evaluasi pengetahuan tentang DBD ini merupakan hasil dari kuisioner pengetahuan tentang DBD yang disebar kepada responden sebelum dilakukannya perlakuan dan sesudah dilakukannya perlakuan. Dan hasil yang didapat dijabarkan dalam bentuk tabel sebagai berikut :

Tabel 2. Tingkat pengetahuan kelompok ceramah dan kelompok leaflet

\begin{tabular}{|l|l|l|l|l|l|}
\hline Variabel & \multirow{2}{*}{$\begin{array}{c}\text { Tingkat } \\
\text { Pengetahuan }\end{array}$} & \multicolumn{2}{|c|}{ Ceramah } & \multicolumn{2}{c|}{ Leaflet } \\
\cline { 3 - 6 } & & Pre-test & Post-test & Pre-test & Post-test \\
\cline { 3 - 6 } & & $\%$ & $\%$ & $\%$ & $\%$ \\
\hline Pengetahuan & Baik & 31.6 & 90 & 5 & 70 \\
& Kurang & 68.3 & 10 & 95 & 30 \\
\hline Total & & 100 & 100 & 100 & 100 \\
\hline
\end{tabular}

Dari Tabel 2. menunjukkan pre-test post-test pengetahuan tentang DBD dapat dilihat pada kelompok ceramah pre-test hanya 31,6\% yang pengetahuannya dapat dikategorikan baik tingkat pengetahuaannya dan yang dikategorikan kurang tingkat pengetahuan sebanyak $68.3 \%$, pada posttest pengetahuan responden meningkat sebanyak $90 \%$ dikategorikan baik dan $10 \%$ masuk dalam kategori kurang. Sedangkan pada kelompok leaflet pre-test hanya sebanyak 5\% mempunyai tingkat pengetahuan baik dan sebanyak 95\% dikategorikan tingkat pengetahuan kurang, pada saat post-test meningkat $70 \%$ dikategorikan baik tingkat pengetahuannya dan sebanyak $30 \%$ dikategorikan tingkat pengetahuan kurang.

Tabel 3. Hasil uji beda rata-rata pre-test post-test dan uji signifikansi pengetahuan, sikap dan kebiasaan kelompok ceramah dan leaflet

\begin{tabular}{l|l|l|l|l|l}
\hline Kelompok & Variabel & $\begin{array}{l}\text { Mean pre- } \\
\text { test }\end{array}$ & $\begin{array}{l}\text { Mean } \\
\text { post-test }\end{array}$ & Selisih mean & Sig.(2 tailed) \\
\hline Ceramah & Pengetahuan & 8.00 & 11.00 & 3.00 & 0.000 \\
Leaflet & Pengetahuan & 6.63 & 9.41 & 2.78 & 0.000 \\
\hline
\end{tabular}

Berdasarkan Tabel diatas dapat dilihat pada kelompok ceramah nilai $p=0.000$ yang artinya terjadi perubahan peningkatan nilai dari pengetahuan atau adanya perubahan pengaruh setelah 
dilakukanya promosi kesehatan dengan metode ceramah didapatkan hasil $p=0.000$ yang artinya terjadi perubahan peningkatan nilai dari pre-test dan post-test variabel pengetahuan atau adanya perubahan secara statistik sesudah dilakukan promosi kesehatan dengan metode leaflet.

Dapat dilihat dari nilai rata-rata terjadi kenaikan pada kelompok ceramah sesudah diberikan promosi kesehatan menggunakan metode ceramah terhadap pengetahuan responden tentang DBD. Berbanding lurus dengan penelitian Pramiputra (2014) mengatakan bahwa pendidikan kesehatan menggunakan metode ceramah terhadap pengetahuan responden tentang DBD dapat mempengaruhi peningkatan pengetahuan.

Tabel 4. Nilai signifikansi metode ceramah dan metode leaflet

\begin{tabular}{|l|l|l|}
\hline Metode & Variabel & Sig.(2-tailed) \\
\hline Ceramah-Leaflet & Pengetahuan & 0.000 \\
\hline
\end{tabular}

Dari tabel uji Mann whitney, dapat disimpulkan terdapat perbedaan pengaruh yang signifikan antara variabel pengetahuan, sikap, kebiasaan metode ceramah dan leaflet $\mathrm{p}=0.000<$ dari 0.05 dan metode ceramah lebih efektif dari pada leaflet karena selisih mean lebih besar pada metode ceramah dapat dilihat pada tabel diatas. Hal itu dipengaruhi oleh antusias responden pada promosi kesehatan pada media ceramah dengan media yang menarik dan penjelasan yang jelas serta gampang dimengerti sehingga responden pada promosi kesehatan metode ceramah lebih signifikan dan lebih efektif pada penelitian ini. Kedua metode memiliki perbedaan skor perilaku sebelum dan sesudah diberikan promosi kesehatan dengan metode ceramah dan leaflet. Hasil penelitian ini membuktikan bahwa promosi kesehatan dengan metode ceramah sebagai salah satu alternatif untuk meningkatkan pengetahuan, sikap dan kebiasaan keluarga masyarakat tentang DBD.

\section{Kesimpulan}

Pemberian promosi kesehatan dengan menggunakan metode ceramah lebih efektif dibandingkan dengam metode leaflet untuk mempengaruhi perubahan pengetahuan responden dengan nilai $p=0.000$.

Acknowledgments: Terima kasih penulis sampaikan kepada semua pihak yang mendukung penelitian ini.

Conflicts of Interest: The authors declare no conflict of interest 


\section{Daftar Pustaka}

Achmadi, U. A., 2010. Demam Berdarah Dengue. Buletin Jendela Epidemiologi, [e-jurnal] 2:48.

Alfianur, 2017. Pendidikan Kesehatan Pencegahan Penyakit Demam Berdarah Metode Ceramah Dengan Media Leaflet Pada Siswa Kelas 5. Adi Husada Nursing Journal, 3(2): 1-10.

Anonim, 2019. Kejadian Luar Biasa Demam Berdarah Dengue (DBD) Di Kabupaten Lamongan. Tersedia di: https://lamongankab.go.id/dinkes/kejadian-luar-biasa-klb-demam-berdarahdengue-di-kabupaten-lamongan/ [20 November 2019].

Anonim, 2018. Situasi Penyakit Demam Berdarah Di Indonesia 2017. Journal of Vector Ecology, 31(1): 71-78. Tersedia di: https://doi.org/10.3376/1081-1710 [01 Desember 2019].

Effendi, S. U., Shaluhiyah, Z., dan Widagdo, L. 2018. Persepsi Masyarakat Tentang Isi Media Promosi Kesehatan Demam Berdarah Dengue ( DBD ) di Kota Bengkulu. Higiene, 4(2): 99108.

Kurniawan, R., Putra, F. H., 2016. Pengelompokkan Wilayah Bencana Endemi Demam Berdarah Dengue Di Jawa Timur Dengan Fuzzy Geographically Weighted Clustering - Particle Swarm Optimization. Jurnal Aplikasi Statistika dan Kompetisi Statistik, 7(2): 27-37.

Kusumawati, Dian., 2014. Hubungan Pekerjaan, Pendidikan dan Pengetahuan Ibu Tentang Makanan Pendamping Asi Dengan Status Gizi Balita Usia 7-24 Bulan Di Desa Waru Karanganyar Kecamatan Purwodadi Grobogan. Skripsi. Universitas Yogyakarta.

Notoatmodjo, S., 2003. Pendidikan dan Perilaku Kesehatan. Jakarta: Rineka Cipta.

Pantouw, R. G., 2017. Hubungan Pengetahuan Dan Sikap Masyarakat Dengan Tindakan Pencegahan Penyakit Demam Berdarah Dengue di Kelurahan Tuminting. Jurnal Kedokteran Komunitas Dan Tropik, 5(1): 217-221.

Pramiputra, A. 2014. Efektifitas Pendidikan Kesehatan Menggunakan Metode Ceramah Dengan Leaflet Terhadap Peningkatan Pengetahuan Pencegahan Demam Berdarah Dengue Di Desa Wonorejo Polokarto. Naskah Publikasi, 53(9):1689-1699. Tersedia di: https://doi.org/10.1017/CBO9781107415324.004 [10 November 2019]. 